\title{
Wounds and Words: The Traumatic Memory in Omar El Akkad's Dystopian Novel
}

\author{
Hasanul Rizqa \\ Department of Literature, Faculty of Humanities, Universitas Indonesia \\ e-mail: hasanul.rizqa@mail.ugm.ac.id
}

\begin{abstract}
This paper discusses the literary portraying of personal trauma in Omar El Akkad's dystopian novel American War. The purpose of this research is twofold: (1) identify the way in which the traumatic memory of war victims is transmitted from the first generation to next generation and (2) understand how the narrator constructs his discourse about the future of America and the world. The method used in this research is descriptive qualitative. The researcher uses Christa Schönfelder's theory on postmodern trauma texts. This research shows that the main narrator's choice to positioning Sarat as a war victim, not a perpetrator of biological genocide, makes the narrative of Sarat's traumatic memory political. It exposes that the first generation's desire for personal narration becomes unnarratable, and that there is second/third generation's urge for a future beyond trauma. The conclusion proves that American War contains the quest for stability out of disruptive experiences, constituting a crucial aspect of the need for narrative in the face of a dystopian future.
\end{abstract}

\section{Keywords}

America, dystopia, postmodern, trauma, war

\section{Introduction}

Omar El Akkad (36 years) is an author who has a background in journalism and immigrants. He was born in Cairo (Egypt) and spent childhood in Doha (Qatar) before following his family to migrate to Canada from the age of 16 . During his ten years as a journalist for The Globe and Mail, he had covered the Afghanistan War, the military court at Guantanamo, the Arab Spring demonstration in Egypt, and the effects of climate change in Florida and Louisiana. (Akkad, 2017, p. 386; Alice Cary's interview in Book Page, 2017).

American War is Omar El Akkad's debut as a writer. Kröller (2017,

Citation. Rizqa, H.: Wounds and Words.: The Traumatic Memory in Omar El Akkad's Dystopian Novel. In. D. Ekawati, et al (eds.): Proceeding of The American Studies International Conference 2018, Vol. 2, pp. 1-6. pp. 41-48. UGM Digital Press Social Sciences and Humanities, Yogyakarta (2019).

Published: May, 2019 p. xli) classifies the novel that was published in 2017 into the Canadian literature. However, until recently, American War reaps appreciation from critics in various international mass media. They are, among others, are Lucy Scholes at The Independent (August 30, 2017), Michiko Kakutani at The New York Times (March 27, 2017), and Laura Miller at The Guardian (October 4, 2017). Those critics broadly praise the novel as a young-adult dystopia. 
Dystopian works reflect society's worries (Demerjian, 2016, p. 1). The term dystopia was first introduced by John Stuart Mill in 1868 to show the opposite of utopia (Vieira, 2010, p. 16). Broadly speaking, dystopia means a gloomy vision about a society, usually, in the future. The authors of dystopia fiction reject the view that a society can reach its ideal situation in which everything is fine.

Dystopian literature in the contemporary American context relates, among others, to the political and security situation as well as traumatic pasts. For example, the inauguration of Donald Trump as president of the 45th United States. It triggered an increase in sales of dystopia novels, both classical and contemporary (Kröller, 2017, p. 224). The American War's release year coincided with the start of the Trump Era. However, Akkad rejected the assumptions that his novel somehow has something to do with it. "I certainly did not refer to write for the Trump era," he said (Martyn Wendell Jones's interview on the website of the University of St. Michael's College, 2017). He tended to associate the emergence of the novel with something more past than Trump's presidency, namely the trauma that accompanies the Global War on Terrorism (GWOT).

GWOT is the response to the 9/11 terrorist attacks. According to Buckley and Singh (2006, p. 12), GWOT is one of the pillars of the Bush Doctrine. The core of the doctrine is that the United States claims the right to attack any country, which it considers as the owner of weapons of mass destruction (WMD) or a terrorist protector. Afghanistan became the first country to experience military invasion in the context of the Bush Doctrine on October 7,2001 . As of 2016 , approximately 111,000 civilians in that country have died as a result of the war (Crawford, 2016).

As mentioned earlier, Akkad as a reporter once covered the Afghanistan War. In relation to the context of the emergence of American War, Akkad also got the impression of the war victim's trauma through media. He remembered watching a talk show on television. The speaker of the event was a foreign policy expert who said that sometimes the U.S. special forces in Afghanistan do nighttime raids and ransack the houses as well as hold women and children at gunpoint.

The expert concluded that in Afghan culture such acts is considered very offensive. Therefore, it could be understood that some Afghan people do demonstration protesting against the U.S. military presence there. Akkad was shocked when he heard the expert's statement. "I have this in mind-taking things that have happened to people very far away and reciting them as elements of something very close to home," he said. The writer saw the traumatic experience felt by war victims as inspiration for writing American War (interview at CBC Radio, 2018).

In this study, American War will be positioned not only as a dystopian novel, but also postmodern one. The transition from the era of modernist to postmodernist fiction is known to have begun since the emergence of Samuel Beckett's trilogy (Molloy, Malone Dies, and The Unnamable) in the 1950s (McHale, 1987, p. 12). Therefore, American War should be seen as one of the most recent postmodern novels, especially in Canadian literature. The grouping is not only based on the temporal factor, i.e. the emergence of the novel, but also the characteristics of the postmodern trauma text, as stated by Christa Schönfelder.

This study will show the representation of trauma in American War. This will be associated with internally displaced persons (IDPs) as the focus of the story. American War is about the life journey of a young woman, Sara T Chestnut (Sarat). She changes over the course of the story, that is, from an ordinary citizen to a refugee girl and finally a genocide perpetrator. The story is narrated by her nephew, Benjamin Chestnut, who is also a respected historian in the aftermath of the American Second Civil War as well as the "The Quick" plague at the beginning of the $22^{\text {nd }}$ century. Benjamin wrote the narrative based on the Sarat's diaries which he discovered decades after the bitter separation between him and his aunt.

The method used in this research is qualitative descriptive. Data may be pictures and/or words. The results of the analysis will be a description which is then interpreted by the researcher. Therefore, the meaning of the entire research object could be revealed. Christa Schönfelder's theory of postmodern trauma texts will be used. The research question in this study is "How are the traumatic narratives constructed in American War?" The hypothesis of this study is that the main narrator plays a significant role in shaping the trauma narratives of Sarat, as a war victim-not a genocide perpetrator-and, therefore, makes the narrative of Sarat's traumatic memory political.

\section{Theoretical Framework}

Schönfelder's theory is used here because it tends to focus on individual and personal trauma, rather than a collective one. Schönfelder also examines the experience of trauma from childhood and in the family sphere. This is in accordance with the content of American War. According to Schönfelder $(2013$, p. 38), 
postmodernism views trauma as an experience that shakes individual life, without having to reduce the individual experience to universal condition. Therefore, this perspective presupposes the importance of ethics in the study of trauma (Schönfelder, 2013, p. 38).

The word trauma comes from Ancient Greek which means "a violent injury from an external cause that breached the body's integrity" (Brette in Schönfelder, 2013, p. 14). The study of trauma related to psychology and psychiatry. The Vietnam War (1955-1975) became an important milestone that increased public awareness of the dangers of mental stress due to trauma. In 1980, Posttraumatic Stress Disorder (PTSD) for the first time entered into the main psychiatric reference book, Diagnostic and Statistical Manual of Mental Disorder (DSM) (Schönfelder, 2013, p. 43).

Schönfelder highlights that the definition of trauma in DSM-IV tends to be paradoxical because it oscillates between objectively seeing traumatic events and observing the subjective responses of the individuals who experience these kinds of events. The latest DSM, DSM-5, completely discards observations of individual subjective responses. Schönfelder (2013, p. 63) considers that trauma fiction does not have to follow (current) DSM in defining trauma. The text of fiction tends to emphasize the reactions, feelings, and minds of the individual, instead of considering any kind of traumatic event objectively. Regarding postmodern trauma fiction, Schönfelder (2013, p. 16) borrows the concept of a literary critic, Linda Hutcheon, who believes that postmodern texts are fundamentally political in nature, i.e. focusing on the marginal groups, the oppressed, and the muted as well as forgotten groups in history. Therefore, criticism consciously supports with inferior groups within the political structure.

Schönfelder (2013, p. 20-21) defines trauma as follows:

“[...] a profoundly distressing, painful, or shocking experience that affects the individual so deeply as to cause a disruption in, injury to, or breach within the structures of the mind and the psyche and that, as a result, may have a persistent impact on an individual, especially regarding his or her relation to identity, memory, and the social environment."

Schönfelder (2013, p. 316) also finds that the narrator-someone who narrates trauma text-in postmodern fiction tend to be consciously involved in memory recovery. Such narratives explicitly equate past reconstruction with the efforts to overcome the memory crisis. Furthermore, postmodern trauma fiction is known to display optimism regarding the possibility of healing for trauma sufferers.

There are trauma sufferers who choose death over life. There are ones-the survivors-who choose the opposite. Postmodern trauma fiction presents efforts, both implicit and explicit, from the survivors to create meaning and stability out of disruptive traumatic experiences (Schönfelder, 2013, p. 322). This requires a person to be ethical, namely recognizing the (post-)traumatic suffering of victims, but at the same time, he or she does not view them as helpless persons (Schönfelder, 2013, p. 320).

\section{Results and Discussion}

Chestnut family lives in the context of the Second American Civil War which takes place between 2074 and 2095. The war is portrayed as the continuation of historical Civil War that took place in 1861-1865 in the United States. Just like Civil War, the war in the novel also named the belligerents as the Union and the South (the Free Southern States). However, the trigger of this imagined war is completely different from the factual-historical reality of the nineteenth century.

The primary cause of the Second American Civil War was Southern resistance to the Sustainable Future Act, a bill prohibiting the use of fossil fuels anywhere in the United States. The bill, championed by President Daniel Ki, was in part a response to decades of adverse climate effects and the waning economic importance of fossil fuels. The war's key precipitating events include the assassination of President Ki by a secessionist suicide bomber, Julia Templestowe, in December of 2073, and the deaths of Southern protesters in a shooting outside the Fort Jackson military base in March of 2074.

Benjamin Chestnut is the main narrator in American War. Thus, the entire narrative in the novel, including the story about Sarat, is narrated by Benjamin who in his adult life works as a historian. Near his death, he felt obliged to reconstruct the narrative of the Second American Civil War from his own point of view, because he knew the personal story of his aunt. His goal is for the reader to know the "real reason" behind the deadly plague that accompanies the war.

But there are things I know that nobody else knows. I know because she [Sarat] told me. And my knowing makes me complicit. (p. 16) 
Benjamin, born in 2089, is the only child of Karina Chowdhury and Sarat's oldest brother, Simon Chestnut. When he was six, Benjamin met his aunt for the first time. At that time, Sarat had just been released from the Sugarloaf Detention Facility. It is the Union prison that is located on an island in the middle of the Florida Sea - the former Florida Peninsula that was sunk due to extreme climate change. Since then, Sarat has lived in Simon's house in Lincolnton, Georgia. Simon, Sarat's older brother, was six years older than her. Sarat is now 26 years old. When remembering this childhood, Benjamin used the first-person pronouns, "I".

I ran in for a closer look at our visitor. I hid behind my mother's skirt.

"Benjamin, this is Sarat," she said, pulling me out from behind her. "This is your aunt."

I stared at the towering woman, dumbstruck. I had seen a picture of her once. In the picture, she must have been a teenager, lean and bald-headed, a menacing smile on her face. But what stood in our driveway bore almost no resemblance to that image. [...] She looked old; I'd been told she was my father's younger sister - she was not even thirty years old—but she looked older than him; (p. 304)

The first impression did not dampen Benjamin's curiosity towards his aunt. He recalled that Sarat often quarreled with his mother. Sarat also looks not very kind with his father, although Simon often defends Sarat from Karina's resentment. Benjamin's mother did not like her because she acts as if the Second American Civil War is not over.

“For God's sake, don't you [Sarat] understand? The war is over," my mother screamed. "This isn't Patience, this isn't the front, this isn't the prison they locked you in. You want to keep living in that world, go crawl back into that filthy little shed of yours and live it there. Don't you dare try to pull us into it, you hear me? Don't you dare." (p. 328)

In Sarat's mind, the United States is still divided politically into two belligerents, namely the North versus the South; and that she was a pro-South militiawoman who so much hated the North. For example, an event in the market, in Benjamin's memory, showed such a mindset. The event also exposed, at the same time, that there was still trauma in the Sarat's psyche.

The following weekend, we [Simon's family] went to the Saturday market in Lincolnton. I [Benjamin] didn't expect her [Sarat] to come with us, but when I went outside, I saw her in the car, the passenger seat pushed all the way back. [...] [At the market] I watched her reach for a butcher's knife on the stall table. And then she was moving toward the soldier. [...] The Blue [Union] soldier [...] didn't see her coming. Somewhere in the depths of me, I knew what was going to happen. I started to run, my damaged arm clunky by my side. When I reached her she was a few feet from the soldier's back. She raised the butcher's knife high. [...] I screamed for her to stop. (p. 336)

At least, she did not kill him because the North-clad soldier turned out to be Marcus Exum, her best friend since they were refugee children in Camp Patience. The camp is managed by the international humanitarian agency, Red Crescent, but it was de facto located in the South's territory. In the camp, the Chestnut familySarat, Dana (Sarat's twin sister), Simon, and Martina (Sarat's mother)-lived as refugees for six years, during Sarat aged from six to 12.

One day in 2081, a prominent U.S. (the North) commander was killed by Southern rebel militias. The shot came from the direction of Camp Patience, whereas the commander was at a checkpoint near the camp. A few days later, the North troops stormed the refugee camp and massacred many people, including Martina Chestnut. As for Simon and Dana suffered injuries. This massacre could be considered a traumatic event for Sarat. Following Schönfelder's definition (2013, p. 20-21), the event gave rise to a "painful, or shocking" experience for the individual, Sarat. Indeed, she had heard the issue that the North troops would invade Camp Patience. The issue also caused Marcus and his father courageously to escape from the camp just a few weeks before the massacre.

Sarat's perspective towards the North, before the massacre, tended to be influenced by Albert Gaines' teaching. For most people in Camp Patience, Gaines is considered a spy who works for Southern rebel groups, especially recruiting potential suicide bombers. However, Sarat regarded him solely as a teacher because she learned many things from this man.

“[...] You know well as I do, he [Albert Gaines]'s just an errand boy for all them rebel groups. Comes to places like this looking for anyone dumb enough to strap on a farmer's suit and blow themselves up outside some Northern Checkpoint. Won't be long before he tries to put a farmer's suit on you too."

"He's a teacher," Sarat said. "Nothing more." (p. 175)

Thanks to Gaines, Sarat believed that the North is "the other" who has to be suspected for eternity. The North is "them", while the South is "us." This perspective was so much different than Marcus'. For him, there is no firm difference between the North and the South. 
Sarat pointed northward. “[...] All the times they've put what's good for them ahead of what's good for us. You can go to school a million years down here and they [teachers in Camp Patience] won't have the guts to tell you a single thing about Northerners. But now I'm learning what they're really like"

Marcus observed the land to the north with indifference. "My dad told me the other day that my grandfather was a Northerner," he said.

"Like, he fought for them?" asked Sarat.

Marcus shook his head. "Nah, just worked up there, on the oil trains up in some place called Williston. Died in that big explosion in '69. [...]" (p. 156)

However, Sarat did not see the action of Marcus and his father, who slipped into the North from Camp Patience, as a betrayal. It is difficult to consider her friend other than a deed from ordinary human beings who just want to escape from suffering.

As she'd learned from Albert Gaines about her people's history of mistreatment at the hands of the North, Sarat had grown to loathe the enemy nation beyond the Tennessee line. But in this moment, as she watched her closest friend disappear into that alien land, she wished only that he be safe there. (p. 178)

After the Camp Patience massacre, Sarat's hatred towards the North increased rapidly. Moreover, she did know that it was the North's military invasion doing the slaughter. To avenge them, Sarat agreed to join the Southern rebel group under the direction of Gaines. Since then, Sarat is no longer a refugee, but a militiawoman. This change is in accordance with Schönfelder's theory (2013, p. 20-21), namely that traumatic events "may have a persistent impact on an individual, especially regarding his or her relation to identity."

A-17-year-old Sarat had become a talented sniper. She even assassinated General Joseph Weiland, a prominent North commander when he was at a checkpoint near the North-South border. Since then, she was considered a hero by the Southern elites based in Atlanta. However, shortly after, Gaines betrayed her. The North could finally catch her, whereas Dana was killed by a drone attack. For seven years, Sarat became a prisoner at Sugarloaf.

At Sugarloaf, Sarat had experienced many psychological and physical tortures. She had survived various kinds of torture except one. That was, once, the guards tortured her by trying to drown her into the sea.

"To end the drownings, she [Sarat] admitted to all the crimes with which they charged her---complicity in all manner of insurrectionist violence, things she'd never heard of before. [...] When asked about insurgents she knew, she said all she knew; when asked about those she didn't, she made up plausible lies. [...] There was no lie too big that her fear of drowning couldn't make it true." (p. 295)

Water is such an important marker for detecting Sarat's individual trauma. Feeling drowned, Sarat remembered how she lost her home. Before becoming a refugee, the Chestnut family lived in St James, Louisiana. The area was very vulnerable, both politically and ecologically. Louisiana was ridiculed by Southern States elite as "purple country" because of it not being assertive, whether in favor of the North or South in the Second American Civil War. Meanwhile, the area is increasingly eroded by the rising sea levels. However, this ecological aspect-not a political one-that shook the Sarat's psyche even more, therefore she was willing to surrender before her tormentors: "There was no lie too big that her fear of drowning."

Sarat's release from Sugarloaf took place along with the peace talks between the Union and the South. The negotiations were carried out not because of the South's efforts to free its militias from the Union's capture, but rather the political calculations alone of the Southern elites themselves.

In 2095, Sarat as a former prisoner lived an ordinary life at Simon's house. Sarat realized that Simon was now married to Karina Chowdhury, a Bangladeshi who was then a Chestnut household assistant. Simon and Karina also have a child, namely Benjamin. Benjamin's relationship with Sarat was initially awkward. One day, Benjamin fell while peering at Sarat's room, which located in a greenhouse, near the courtyard of Simon's house. Benjamin accidentally broke his hand. Sarat helped the child. Since then, their relationship began to become stronger.

One day, Benjamin revealed that he has a hobby of swimming. But, he could only swim in a swimming pool in Atlanta. Sarat felt strange for hearing that. Why should Benjamin go all the way to Atlanta to swim, besides there is a river near his house? For one reason, the banks of the river were blocked by walls, two meters in high. Sarat then invited her niece to swim with her in the river. Before jumping over the wall, signs of her trauma were indeed seen. But it was only realized years later by Benjamin.

\footnotetext{
"Sarat stood by the side of the levee. She was tall enough to see past the wall and through the willows. She watched the river. It wasn't until many years later that I understood the courage she was struggling to summon, the demon she had to bury before she could set foot once more into the moving water (p. 341)

I [Benjamin] looked at her then, and I saw a thing I'd never seen before. My aunt was laughing." (p. 342)
}

This happiness signifies that- for a while-Sarat's soul shows stable signs. However, a few days later, Sarat met Joe, Gaines's friend while still in Camp Patience. Joe revealed that he was a Bouazizi Union agent whose real name was Yousef Bin Rashid. The Bouazizi Union has an interest in interfering in the internal 
affairs of the United States through support for the South. The goal is that the United States should not return to being a superpower.

Yousef realized that Sarat still holds a grudge against the Union and South elites. Meanwhile, the Reunification Ceremony will take place in the capital of Union, Colombus, in the next few months. Sarat accepted Joe's offer to infiltrate to Columbus and spread the deadly virus, namely "the Quick".

In a snapshot, the main narrator of the novel (Benjamin) mentions a fragment of a document containing information about Gerry Tusk, an American scientist responsible for the discovery of the virus. Tusk leaked his findings to the Bouazizi Union government in order to get asylum from the Middle Eastern country. During his stay in Cairo, he changed his name to Mahmoud Abd-el-Ghafur. In the document, Tusk is referred to as "a traitor."

Before infiltrating to Columbus, Sarat met Marcus-after accidentally meeting him in the market. Sarat begged him to be willing to escape to Alaska. The "The Quick" outbreak is predicted not to reach Alaska, even though it covers almost all the mainland of the United States, including the Union and South regions. Next, Sarat spoke privately with Simon. She apologized to his brother. For the first time, Sarat cried. This can be interpreted that Sarat consciously chooses death to recover his trauma. Conversations between Sarat and Simon were reconstructed by Benjamin. The day before infiltrating to Colombus, Sarat tricked Benjamin so that he willingly following her. After that, his nephew was met with Sarat's subordinates. They "kidnapped" Benjamin and took him to New Anchorage, Alaska. Finally, the day of the Reunification Ceremony arrived. Sarat managed to infiltrate into Columbus and secretly spread the "The Quick." She committed a genocide.

Since he was six years old, Benjamin lived in the New Anchorage orphanage. When he was 18, he received a letter containing Sarat's handwriting. The letter was sent by Sarat subordinates who had "kidnapped" him before. Benjamin ignored the letter for over 40 years. All this because he was so upset with her. In 2147, Benjamin realized that the letter contained the coordinates in which his aunt probably located for the last time. Following the coordinates, Benjamin arrived in the coastal area of the Florida Sea. He met Layla Denomme Jr., who later was known as a lesbian couple of Sarat while the two women were in Atlanta. The old woman entrusted Sarat's files to him. The files are his aunt's diaries.

Based on the diaries, Benjamin reconstructed the history of the Second American Civil War. The diaries of Sarat should be considered as a trauma memory in which she acts as a narrator-protagonist to her own story. By writing down his memory, Sarat tried to be involved in restoring her own memory. But, paradoxically, she chose death over life in order to take revenge, instead of surviving. Benjamin is a survivor. The construction of the traumatic narrative built in the narrative of American War is his own narrative strategy. However, as the main narrator, Benjamin was free to put forward Sarat's identity as a victim of war, instead of the perpetrators of genocide. By burning almost all the Sarat's diaries, it can be considered that Benjamin had made a desire to tell his aunt's story unnarratable. Even if something is narrated, it is already through the re-construction that Benjamin built as the second or third generation (if we consider Martina Chestnut as the first generation). Benjamin's decision was politically nuanced because it blurred the evidence of Sarat's involvement in the "the Quick" genocide. It became a top secret of the Chestnut family.

So, I chose.

[...] I piled the diaries in a pyre and set them ablaze. If I had wanted to, [...] I could have donated them anonymously to a museum, or to the Civil War Archive Project or to the Committee for Truth and Reunification. But I couldn't keep

myself from burning them. It was the only way I had left to hurt her. (p. 378)

The act of genocide carried out by his aunt is solely regarded as "her last act of cowardice" - It was cowardice because Sarat does not dare to survive as a survivor. By prioritizing the Sarat role as a fearful war victim, the American War narrative could be said to contain the political tendency of the narrator, Benjamin, about a future that goes beyond traumatic events. Trauma that arises because of the dualism perspective in looking at the world, p. "us" and "them." Perspectives that encourage Sarat to carry out genocide. Leaving behind the binary opposition "us-them", Benjamin stabilized the meaning of the (Chestnut) home in the history of the Second American Civil War which was a dystopia. The whole narration closes with such an overview. There's only one page from Sarat Chestnut's diaries I didn't burn. It's the first page of the first book. I [Benjamin] carry it in my wallet, and every now and then I read the opening lines.

When I [Sarat] was young, I lived with my parents and my brother and my sister in a small house by the Mississippi Sea.

I was happy then. (p. 379) 


\section{Conclusions}

American War contains the quest for stability out of disruptive experiences, namely the Second American Civil War. Sarat's diaries constituting a crucial aspect of the need for narrative in the face of a dystopian, traumatic event. But, Benjamin as the main narrator tends to position Sarat as a war victim, not a perpetrator of biological genocide. He has made the narrative of Sarat's traumatic memory political. Sarat's narration as the first generation's desire for personal narration becomes unnarratable. The choice was taken by Benjamin also signified that there is an urge from the next generation to accept more a future beyond trauma. A future in which the individual(s) should be happy. In short, the dystopia future in American War is directed toward utopian "future".

\section{References}

1. Akkad, O. E (2017). American War. New York: Knopf Publishing Group.

2. Cary, A. (2017). Omar El Akkad from the Front Lines to Fiction. Retrieved from https: //bookpage.com/interviews/21147-omar-el-akkad [Accessed on 23 July 2018].

3. CBC Radio (2018). How War Reporting Inspired Omar El Akkad to Write His Debut Novel. Retrieved from https://www.cbc.ca/radio/thenextchapter/antanas-sileika-leannebetasamosake-simpson-jen-agg-1.4141079/how-war-reporting-inspired-omar-el-akkad-towrite-his-debut-novel-1.4141166 [Accessed on 23 July 2018].

4. Crawford, N. C (2016). Update on the Human Costs of War for Afghanistan and Pakistan 2001 to mid-2016. Watson Institute International and Public Affairs Brown University.

5. Demerjian, L.M (2016). The Age of Dystopia: One Genre, Our Fears, and Our Future. Cambridge: Cambridge Scholar Publishing. pp. 1

6. Jones, M.W (2017). St. Mike's Cosponsors Conversation with Novelist Omar el Akkad. Retrieved from https://stmikes.utoronto.ca/news/st-mikes-cosponsors-conversation-with-novelistomar-el-akkad/ [Accessed on 23 July 2018].

7. Kakutani, M. (2017). A Haunting Debut Looks Ahead to a Second American Civil War. Retrieved from https: //www.nytimes.com/2017/03/27/books/review-american-war-omar-el-akkad.html [Accessed on 23 July 2018].

8. Kröller, E.M (2017). The Cambridge Companion to Canadian Literature (Second Edition). Cambridge: Cambridge University Press. pp. xii; 214.

9. McHale, Brian (1987). Postmodernist Fiction. London and New York: Routledge. pp. 12

10. Miller, L. (2017). American War by Omar El Akkad Review - Terrorism in A Future US. Retrieved from https://www.theguardian.com/books/2017/oct/04/american-war-omar-el-akkad-review [Accessed on 23 July 2018].

11. Scholes, L. (2017). American War by Omar El Akkad, Book Review: Should be Read as A Cautionary Tale. Retrieved from https: //www.independent.co.uk/artsentertainment/books/reviews/american-war-omar-el-akkad-review-a7919636.html [Accessed on 23 July 2018].

12. Schönfelder, C. (2013). Wounds and Words: Childhood and Family Trauma in Romantic and Postmodern Fiction. Bielefeld: Transcript. (pp. 14-16, 20-43, 63, 316-322)

13. Singh, R \& Buckley, M. (2006). The Bush Doctrine and the War on Terrorism: Global Response, Global Consequences. London and New York: Routledge.

14. Vieira, F. (2010). The Concept of Utopia. In. Gregory Claeys (ed). The Cambridge Companion to Utopia Literature. Cambridge: Cambridge University Press, pp. 3-27. 